\title{
Education Values in Podang Dance at Napar Nagari Koto Nan Gadang Payakumbuh West Sumatra
}

\author{
Gustia Arini $\mathrm{E}^{1}$ and Yos Sudarman ${ }^{2}$
}

\author{
${ }^{1}$ Universitas Negeri Padang, Padang, Indonesia, $ه$ (email), gustia.arini.unp@gmail.com \\ ${ }^{2}$ Universitas Negeri Padang, Padang, Indonesia, $ه$ (email), sudarmansendra@fbs.unp.ac.id
}

\begin{abstract}
This article aims to reveal the education values in the Podang dance performance at Napar Nagari Koto Nan Gadang Payakumbuh City. The education values contained in the Podang dance performance are forms of Napar community life. The method used in this research is the ethnographic method. The qualitative data was collected through observation, interviews, literature studies, and documentation studies. Data analysis was carried out by determining objects, conducting compound analysis, conducting focused analysis, and determining cultural themes. The results of the study show that in the Podang dance performance there are education values which are so important in social life in Napar. The manifestation of those is the value of religious education, moral education, social education and cultural education. These values are recognized and carried out today by the people of Napar so that these values become important even in the arts and become parts of the Podang Dance performance.
\end{abstract}

\section{Keywords: Education Values, Podang Dance Performance}

\section{INTRODUCTION}

Payakumbuh City is an area loaded with traditions and customs. Every nagari, sub-district, and village has their own traditions and customs wich are still carried out until now. Starting from how to dress, everyday language, various kinds of events held, to the arts played by the community. There are many arts that live and develop in the city of Payakumbuh, one of which is the Podang Dance.

Podang dance is a dance that was born, grew, lived and developed in Napar, the City of Payakumbuh. The Podang dance has been present in the Napar community for a long time, so the creator of the Podang dance is unknown. Podang dance is one of the hereditary inheritances of Napar people whose heirs are not too many. Only a few people are able to dance this dance. The Podang dance is danced by dancers whose age ranges from 28-60 years with a number of 4-5 people from generation to generation.

Podang dance is a dance that features silat movements and swordplay. Podang dance performance features 24 movements, including repetition of movements. Every movement has a certain meaning that gives rise to the values of life for the people of Napar. Podang dance movements include: salam pembuka, barabah mandi, sewa, cubadak Alia, salam kepada penonton, ambiak Podang, cubadak alia, pakai Podang, sewa pakai Podang, Manggureh Tanah, anggar 7, mainda, sewa pakai Podang, Manggureh Tanah, anggar 5, mainda, sewa pakai Podang, Manggureh Tanah, anggar 3, mancatuak, badansu, sipak pacaraian, bagoluik gajah dorong, dan salam penutup.

More than that, in dancing Podang dance, every dancer learning it must follow or meet certain requirements, namely bareh sagantang (1 bushel rice), putiah sakabuang cloth (white cloth approximately 2 meters), knife (made of iron) and piti sapiah (money 1 rupiah, adjusted to the conditions of the times) and the field where the exercise was given chicken blood.

Podang dance is usually played at major events in Payakumbuh City, for example during the Alek Nagari, Batagak Pangulu and welcoming of glorified people who come to Payakumbuh City, such as state and regional officials. Podang dance is usually accompanied by traditional Minangkabau instruments such as Saluang, Gandang Tambua and Talempong.

Podang dance is now rarely used to welcome guests of honor who come to the city of Payakumbuh because at the present time for welcoming guests, people in the city of Payakumbuh prefer to show more interesting dance performances such as Pasambahan dance, Galombang dance or other new creation dances. However, Podang dance is still used in the Alek Nagari and Batagak Pangulu events, or other events whose officials want Podang dance to appear at the event that they (the public) do. Besides, Podang Dance performance is often asked to perform by people who are interested in this dance such as art students and others. Although dance in the city of Payakumbuh is developing very rapidly, but this Podang dance still gets a special place in various events as 
mentioned above. For this reason, Podang Dance is still in existence until now.

The existence of Podang dance which is still maintained until now certainly cannot be separated from the values contained in the dance performance. These values are those exist in the Napar community. They are raised in the Podang dance so that the Podang dance can be accepted, used, and persisted in the supporting community because it reflects the real life of the Napar people.

By seeing and understanding the values contained in the Podang dance performance, what is actually contained in the dance performance, what values are conveyed, what message is given by the Podang dance performance to the community can be found out.

Indrayuda (2017) stated that an art will remain in its owner community if the art is useful for its civilization both for the past, present and future. In addition, an art will survive, grow and develop in a long time in the midst of community life if the art has norms and values that are the same as the values adopted by the supporting community. In addition, the art also has universal values that are relevant to human life.

Yulianti (2015) explained that value is something that is understood by the community about what is meaningful that can be interpreted by the community towards the contribution of something to people's lives. Yulianti sees, for example, from the aspect of history. History will be valuable if it can be understood by society, and history itself gives meaning and contribution to society. Like art, it willgive value if it can provide something valuable and beneficial to society, whether its benefits, meaning given, or knowledge that will be absorbed by the community. Then something will be valued if the value is attached to what will be valued.

According to Gustianingrum (2016), the value of regional cultural arts is the values contained in the culture of the region itself. Cultural values are not easily replaced or removed because the cultural values as stated above are good and are considered valuable and serve as guidelines for behavior. In the Kuda Renggong art, there are also noble values that must be preserved. These noble values are (1) Spiritual / religious values: the spirit that is raised in a series of initiation ceremonies from a boy who is circumcised. The strength of the Kuda Renggong art that appears will imprint upon the circumcision of the circumcised child, as well as the wearing of the Gatotkaca puppet character costume known as a hero figure; (2) the value of interaction between God's creatures: Awareness of the Kuda Renggong art trainers in treating their horses, not solely as befits a pet, but has a tendency to indulge and even position the horse as a creature of a pampered God, both in terms of selection, food, care, clothing, and others; (3) theatrical value: at certain times when the Kuda Renggong art moves up as if standing then underneath the trainer plays silat, dances, and they spark together. Kuda Renggong art looks theatrical because of the horse's position that looks more authoritative and charming. This attraction is a rare performance because not all Horses are able to do it; (4) universal value: since the time humans know horse, it has been a part of human life in various nations in various places in the world. Horses are even used as symbols of strength, virility, heroism, authority, and so on; (5) aesthetic value: in the Kuda Renggongart indeed there is beauty that is shown through the clothes worn by the lively Kuda Renggong art including the children riding it, the musicians and their accompanying dancers; (6) the value of cooperation: in the Kuda Renggongart it can be seen from the presence of togetherness in preserving the cultural heritage of its predecessors; (7) the value of compactness and order: reflected in a performance that can run smoothly; (8) the value of hard work and perseverance: in the Kuda Renggong art the value is reflected in the mastery of dance movements; and (9) social values: in this Kuda Renggong art, the social sense of the community is indeed very wellregarded with mutual care and help in the process of implementing this art. (Gustianingrum \& Affandi, 2016)

There are many values that can be seen from the Podang dance performance. In this case, the writer examines the educational values contained therein. Educational values are complex, but they will provide a pattern of principles which are analytic: knowledge, feelings, willingness, which give order and direction to the flow of thought and action taken by the community. The value of education must be lived and understood by humans because it leads to goodness in thinking and acting so as to develop character and mind.

Nurgiantoro (2007) stated that the value of education can be divided into several parts: the value of religious education, moral education, social education and cultural education. The value of religious education is a value that is not only concerned with aspects of external life but also concerns the total self of a person in its integration of relations into the oneness of God or in other words how it relates to the creator or God. The value of moral education is the value associated with human nobility, which is more related to human behavior in daily life. The value of social education is the wisdom that can be taken from social behavior and social procedures, with regard to society or the public interest. And the value of cultural education is something that is considered good and valuable by a group of people or ethnic groups but is not necessarily seen well by other community groups or cultural groups. Cultural values are the most abstract level of adator rules, rooted in people's minds, and difficult to replace with other cultural values in a short time.

Judging from the meaning contained in the Podang dance performance, the writer can see the educational values inherent in the Podang dance performance and are discussed in more depth by the author. Thus, this writing can be a reading material and cultural documentation in written form as a form of step in preserving traditional art, in this case is the Podang dance.

\section{METHOD}

This qualitative research was conducting by using descriptive analysis method. This qualitative method has the characteristics of a naturalistic paradigm, which is 
relevant to the object of research, namely the education values contained in the Podang Dance performance at Napar, Payakumbuh City. Qualitative research is conducted directly to the source or object of research and it produce data. Qualitative research is descriptive. In other words, it reveals and demonstrates the methods used to obtain data from the field.

By using qualitative methods, the data obtained about the Podang Dance in Napar, Nagari Koto Nan Gadang, will be more complete, deeper, and meaningful, so that the objectives of this study can be achieved.

The instrument in this study is the researcher himself as a key instrument and is equipped with observation guidelines and interview guidelines so that the researcher can systematically trace the desired qualitative data in accordance with the research problem. In addition, researchers also use other instruments such as directional, undirected and in-depth interviews, and observation.

The techniques used in collecting data were Literature Study, Observation, Interview, and Documentation. Data Analysis Techniques are started from data collection, data reduction, data presentation, and drawing conclusions / verification.

To guarantee the validity of the data in this study, researchers conducted: 1) Recording the results of data collection. The final results in this study, among others, depends a lot on how detailed, accurate, and extensive the recording of the results of data collection. Recording is a standard in the analysis of data obtained from observations and interviews. 2) Recording and photographs. Recording and taking photographs are intended to be physical evidence and guarantee the accuracy of the data obtained. 3) Triangulation. Triangulation in this study was carried out by utilizing sources, researchers, and theories. The process of triangulation is done by comparing the results of interviews with the reality on the ground, comparing what is done by the performers while performing with what is delivered privately, comparing data obtained with other research and relevant theories. Triangulation techniques are carried out repeatedly to check the trustworthiness and validity of data from informants, namely key informants and supporting informants

\section{RESULT AND DISCUSSION \\ A. Results}

As explained earlier, there are several types of education values according to Nurgiantoro (2007). They are the value of religious education, moral education, social education and cultural education. It was found that the four education values above were found in thePodang Dance performance. For more details, the following will explain each of the education values contained in the Podang dance performance:

\section{a. The Value of Religious Education in the} Podang Dance performance

The value of religious education is the value of education that aims to educate humans to become better human beings according to religious guidance and always remember God. The value of religious education guides us how to become a human beings who arethe creatures of Allah SWT. This is done by always realizing and remembering that we were born in the world by carrying certain obligations and goals towards Allah SWT. Thus, the value of religious education will always remind us of the attitudes and behaviors that we must always show before God Almighty by doing acts of worship and good deeds as much as possible.

The value of religious education in the Podang dance performance as explained by Jhon Anandri Dt lelo Sati, Zamri and Isrizal is from several movements that are danced and have profound meanings about religious values such as the movements of Manggureh Tanah, Anggar 7, Anggar 5, dan Anggar 3-Catuak.

The Manggureh Tanah Movement means we must remember that we are human beings, creatures created by God, made of earth and will return to the ground. This teaches us about our nature as humans are as people of God who are placed on earth because of the will of Allah SWT. As humans, we must remember that someday we will be returned to Him through the ground after we die.

We are taught to always remember what thingswe must bring for death. It helps us answer are our deeds enough to save ourselves before Allah SWT and get the best place in His side, Heaven.

The Manggureh Movement teaches us to always remember that we will not be eternal on this earth and when we are called back, are we ready to begin the first test, which is in the tomb in the ground, when angels ask our questions of faith at that time.

The value of religious education can also be seen from the Anggar 7movement which symbolizes or has a meaning of 7 layers of heaven, 7 kinds or names of heaven and 7 kinds or names of hell. This will provide education to us that in the sky visible to us there is still a sky above it. This teaches us that as human beings we should not be arrogantand consider ourselves better in all respects. We must remember that above all, Allah SWT is the Almighty of all things and dominates the whole world and its contents.

The value of religious education that we can also take from the meaning of 7 types or names of heaven and hell is that every deed and attitude of our worship will be calculated by Allah SWT without missing even the slightest and we will get a fair reward from it all. There will not be the slightest error in the calculation and judging process done by Allah SWT. We will be rewarded according to what we have done whether it is something good or bad.

Anggar 5 movement steaches us the things we must do as humans who embrace Islam. This can be understood through the five pillars of Islam, namely: say the two sentences of shahada, establish prayer, fast, pay zakat and go on pilgrimage if you can. Anggar 5 movementseducates us to always remember our nature, duties or obligations as people who embrace Islam.

Anggar 3-Catuak movement is interpreted as the number of our calculations when taking ablution 
before prayer. Catuak is a movement that reflects the prayer itself. Gerak Anggar 3teaches us how to purify properly and right before we pray. Before we deal with Allah SWT or meet Allah SWT through the prayers that we do we should purify ourselves first from the things that pollute our bodies. This is due to the fact that Allah likes clean people.

Apart from the movements above which contain the value of religious education, the value of religious education can also be seen from the conditions performed by dancers before practicing Podang dance, namely: Kain Sakabuang and Bareh Sagantang. Both of these conditions educate and teach us that we must always remember Allah SWT and always give thanks for all the sustenance and favors that he has given. Do not be a proud, arrogant, even kufr human beings for everything that $\mathrm{He}$ has given. As human beings, we must realize that we are nothing compared to Him, the all-powerful God,

In addition, we must also remember that we will not live eternally on this earth.When the time comes, God will call us back to account for everything we have done. Have we prepared ourselves before him?This is due to the fact that we cannot know when, where, and in what way He will call us. We should have enough provision in the form of acts of worship and good deeds as much as possible.

The real evidence that can be seen from the value of religious education given by the Podang dance according to Jhon Anandri Dt lelo Sati is that if we look at the past. It is the youths who diligently and obediently pursue religious knowledge, study Islam. At the present time, we can also see it even though it is not like in the past and the method has also been changed. It can be seen through Taman Pendidikan Al-Quran (a place for learning Al-Quran), Prayers and the provision of religious knowledge to children and adolescents after the evening prayers in the mosque or mushala in Napar village.

\section{b. Moral Education Values in the Podang}

\section{Dance Performance}

The value of moral education contained in something that aims to educate humans to recognize ethical values. It is a good or bad value of an act related to what must be avoided and what must be done. Thus, it is to create an order of human relations in society that is considered good, harmonious and beneficial for that person, the community, and the natural surroundings.

The moral education values contained in the Podang Dance performance can be seen from the meaning that emerged from the Podang dance movements, among others, the gesture of respect or opening greetings, the Barabah Mandi movement, Sewa, Greetings to the audience, and the last respect or closing greetings. The meaning of these movements will educate us as human beings to become individuals who have good manners, ethics, and respect for others regardless of their background. Especially Minangkabau people who have rules or guidelines in which we must be able to position ourselves well, socialize well, and be able to position others according to their age: how we communicate with older people, younger people, peers and people who should be respected so that we are not considered as humans who do not have ethics or in the Minang language are often called "Indak Bataratik".

This Podang dance movement also teaches us to always maintain cleanliness of our bodies, minds, and hearts. We should be able to maintain that cleanliness, always be prejudiced from negative thoughts towards both ourselves and others, and keep away from various socialproblem that can damage our relationships with humans or society.

The moral education values that exist in the Podang dance performance also educate us to become human beings who are aware of ourselves (know ourselves). We should be able to pay attention to the situation and take advantage of time. If we start something well we should end it with good things too. The Minangkabau tradition teaches "Datang Tampak Muko Pai Tampak Pungguang". It is expected that we have a good personality, good ethics, and have procedures in life that can be emulated by other communities.

Apart from the above movements, the value of moral education can also be seen from the conditions in the Podang dance before the dancers conduct training, namely Pitih Sapiah and Basi or Pisau. Pitih Sapiah and Basi teach us not to judge life from material aspects. Material is indeed very much needed but it is not the main thing in life. Not everything we can count or we buy with money. There are many things we get without money as intermediaries, such as love, affection, respect and respect, sacrifice, loyalty, trust and so forth. This educates our hearts, feelings, and morals to be more subtle and sensitive to the things around us. This will help us to become better personalities and can be used as useful examples by others.

Pisauor basi teaches us to be strong, brave, upholding principles and resistant to exposure. This teaches us to be wise and strong in dealing with life. It teaches us about how to be a human who has a noble nature that is able to fight for rights and realize their obligations. Thus, he will be a role model or even become a teacher for the people around him.

The application from the value of moral education given by the Podang dance to the Napar urban community can be seen from how the Napar urban community is able to position themselves in society by adjusting to the rules, norms, laws and customs that apply in the Napar. It also can be seen through how they areable to be kind, respect others, and benefit the people around him.

\section{c. The Value of Social Education in Podang} Dance Performance

The value of social education is related to matters involving society or the public interest. The value of social education will make people become aware of the importance of group life in a family bond between one individual and another individual. The value of social education refers to the relationship of individuals with other individuals in a society. It relates to how someone 
must behave, how they solve problems, and how they deal with certain situations in life.

A statement regarding the value of social education above can be found in the Podang dance performance. The value of social education in Podang dance can be seen through the meaning of the motion that is contained in several Podang dance movements, namely the Cubadak Alia movement, the Badansu movement and the Bagoluik movement. The meaning of these movements teaches us how we should live our daily lives. In living our lives, we must always be careful, be aware of whatever we will face now or in the future. We must be able to determine attitudes, make decisions and do things by considering the pros and cons, both for our own interests and those related to the interests of others.

In this life, we are also expected to be able to prepare ourselves with whatever conditions we will live, the good and bad of life, whether or not we are lucky in life, we must still live and be positive and always try to be better without having to sacrifice ourselves and feelings to other people. Live our lives as well as possible without having to be parasitic in the lives of others or distressing others. We must realize that the circumstances in life will always turn and change, therefore, as fellow human beings we must help each other unconditionally because we cannot know how our lives will continue, maybe we will be on top or even vice versa .

In addition, the lesson we can take from the meaning of the Podang dance movement is how we should place ourselves in communicating and socializing with others or with community groups by communicating well, joking, and sharing stories and useful information. Of course in conducting such communication we must still obey the limits when speaking, by not offending others, or entering the limits of other people's personal problems.

Thus, everything we learn about the value of social education from the Podang Dance performance can help or guide us to be able to become human beings who are able to socialize well with the community and environment where we live or where we are.

\section{d. Cultural Education Values in the Podang} Dance performance

Cultural values are something that is considered good and valuable by a group of people or ethnic groups. Cultural values limit and give characteristics to a society and its culture. Cultural values are the most abstract level of adat, live and are rooted in people's minds, and are difficult to replace with other cultural values in a short time.

The Podang dance performance is a performance that displays the Minangkabau traditional art that originated from Napar, Koto Nan Gadang, which reflects the face and characteristics of community life in ancient times. The Podang dance performance displays a work of art that was raised through Silek movements and Podang game expertise. For the present, this show will provide the current generation with knowledge about their traditions and culture that they must know. It must not just disappear. Instead, it must be maintained.
The Podang dance performance contains the noble values of the life of the people of Nagari Koto Nan Gadang. It provides knowledge and teaching, and it educates us to become better human beings for ourselves, others, society, or the environment

Podang dance is one form of culture in the form of art that was born and grew up in the Napar, Nagari Koto Nan Gadang. It contains religious, customary, and social teachings that are very beneficial to humans, especially the Minangkabau people who highly uphold the rules religion, customs, and social in the community

Based on the above explanation, the Podang dance performance contains the value of cultural education that can be learned for the performers and audience. The actual cultural values must be known by the Minangkabau people since those values are needed in living their daily lives.

\section{B. Discussion}

According to Nurgiantoro (2007), there are several education values that must be lived and understood by humans to become better human beings, and develop character and mind. The first value is the value of religious education. It is the value that aims to educate humans better according to religious guidance. The second, value of moral education. It is the value associated with human behavior and educating humans to judge a good, bad, what should and should not be done and know the ethical values in life. The third value is the value of social education. It is the value that refers to the relationship of individuals with other individuals, individuals with nature and the surrounding environment in social society. The fourth is the value of cultural education that is the value of education that is considered good for a group of people that characterizes the community and gives the characteristics of the community.

The four educational values expressed by Nurgiantoro were also found in the Podang Dance performance. The value of education in the Podang dance performance can be seen through the movements carried out. The movements have the meaning in which we as human beings must remember that we have duties or obligations and goals before God Almighty. This is a clear example of the relationship between humans and the God, which is related to the religious guidance adopted by Islam. The educational value in the Podang dance performance can be seen from some of the movements that are danced which have profound meanings about religious values namely the movements of Manggureh Tanah, Anggar 7, Anggar 5, and Anggar 3-Catuak. The value of education teaches us that as human beings we should not be arrogant, educates us to always remember the nature, duties or our obligations as a people who embrace Islam. It teaches us to always give thanks for all the blessings and favors that God has given, leading us to become better human beings in accordance with the guidance of religion.

The moral education value contained in the Podang Dance performance can be seen from the meaning that emerged from the Podang dance movements, among others, the gesture of respect or opening greetings, the 
Barabah Mandi movement, Sewa, Greetings to the audience, and the last respect or closing greetings. The meaning of these movements will educate us as human beings to become individuals who have good manners, ethics, respect others regardless of their background. Especially the Minangkabau people who have rules or guidelines that we must be able to position ourselves well. It teaches to always be a kind human being, be clean in terms of body, mind, and heart. Always being prejudiced keeps away from the mind towards others and keeps away from various social problems that can damage our relationship with humans or society. In addition, these movements also teach us not to judge life from material aspects. Material is indeed very much needed but it is not the main thing in life. It educates us to be wise, stand firm, and strong in facing life.

The value of social education in Podang dance can be seen through the meaning of the motion that is contained in several Podang dance movements. They are the Cubadak Alia movement, the Badansu movement, and the Bagoluik movement. The meaning of these movements teaches us how we should live our daily lives. This movement also teaches how we should place ourselves in communicating and socializing with others or with community groups and the surrounding environment.

Cultural education values contained in the Podang dance performance are performances that reflect the faces, and characteristics of community life in ancient times. Podang dance performances are raised through Silek movements and Podang game expertise. This show will provide the current generation with knowledge about their traditions and culture that they must know. It must not just disappear. Instead, it must be maintained.

The Podang dance performance contains the noble values of the life of the people of Nagari Koto Nan Gadang. It provides knowledge and teaching, and it educates us to become better human beings for ourselves, others, society or our environment. Podang dance is one form of culture in the form of art which contains religious, customary, and social teachings that are very beneficial to humans, especially the Minangkabau people who highly uphold religious, customary, and social teachings in their society.

\section{CONCLUSION}

Podang dance performance contains educational values that we can learn as guidelines in living life, such as religious education values, moral education values, social education values and cultural education values. These values are accepted, used, and absorbed into the lives of people in Napar as Podang dance owners. Every movement displayed in the Podang dance performance has a deep meaning. From those meanings, the values of people's life in Napar emerge as a reflection of the life of the community itself.

\section{ACKNOWLEDGMENTS}

This research was funded by Universitas Negeri Padang and was facilitated by the dean of the Faculty of
Language and Art of Universitas Negeri Padang. Due to this, I would like to thank the Chancellor, the Dean, and the entire academic community of Padang State University. Along with that to the students and lecturers of Sendratasik FBS UNP, who have helped collect data.To all of them, I'd like to say thank you. The special words I give to my research informants Tuo Tari Podang, Jhon Anandri Dt lelo Sati, Yusrizal, Zamri, Isrizal and Sukarman as well as Podang Yan Putra Utam dancers and Meki Dio Fenando for their services in assisting the implementation of this research.Special thanks to everyone who cannot be mentioned one by one in this paper. Hopefully,the help will be a charity.

\section{REFERENCES}

[1] Gustianingrum, P. W., \& Affandi, I. (2016). Memaknai Nilai Kesenian Kuda Renggong dalam Upaya Melestarikan Budaya Daerah di Kabupten Sumedang. Journal of Urban Society's Arts. https://doi.org/10.24821/jousa.v3i1.1474

[2] Indrayuda., "The Domination of Female in Galombang Dance: Between Traditional Idealism and Use to Performing Arts Market," Jurnal Harmonia 17 (2) (2017)

[3] Yulianti, Iing. "Pewarisan Nilai-nilai Budaya Masyarakat Adat Cikondang dalam Pembelajaran Sejarah Madrasah Aliyah Al-Hijrah" Jurnal Candrasangkala Pendidikan Sejarah 1 (1), 112 133 (2015).

[4] Nurgiantoro, Burhan. 2005. Teori Pengkajian Fiksi. Yogyakarta: Gadjah Mada University Press. 